\title{
Effect of formaldehyde-treated urea on rumen fermenta- tion, ration digestibility and nitrogen utilization
}

\author{
JOUKO SETÄLÄ and LIISA SYRJÄLÄ-QVIST \\ Department of Animal Husbandry, University of Helsinki \\ 00710 Helsinki 71, Finland
}

\begin{abstract}
The study comprises two experiments in which young Finn-sheep were used as test animals. The experimental rations consisted of equal parts of $\mathrm{NaOH}$-treated wheat (Exp. 1) or barley (Exp. 2) straw and a concentrate mixture of barley-molassed beet pulp (Exp. 1) or barley-oats-molassed beet pulp (Exp. 2). Feeding was performed twice a day. In addition $20 \mathrm{grams}$ of urea/animal/day was mixed into the concentrates just before feeding.

The urea was treated with the following percentages of formaldehyde, on a weight basis: $0\left(\mathrm{~F}_{0}\right), 1.0$ $\left(\mathrm{F}_{1.0}\right), 3.0\left(\mathrm{~F}_{3.0}\right)$ and $5.0\left(\mathrm{~F}_{5.0}\right)$ in Exp. 1 and $0,1.0$ and 1.5 $\left(\mathrm{F}_{1.5}\right)$ in Exp. 2.

The digestibility of the total ration decreased, when $F_{3.0}$ and $F_{5.0}$ urea was used, but the decrease was significant $(P<0.05)$ only when the apparent digestibility of crude protein was compared between the $F_{0}$ and $F_{5.0}$ diets. The amount of rumen bacteria was decreased $(P<0.05)$ and the amount of protozoa increased $(P<0.01)$ by formaldehyde treatment levels above $F_{1.0}$ and $F_{3.0}$, respectively.

The concentration of the total VFA in the rumen tended to decrease with treatment levels higher than $F_{30 .}$. No significant differences were found in the composition of the VFA.

When treated urea was used, the excretion of nitrogen in the faeces increased but its excretion in the urine decreased. The percentage retention of the nitrogen ingested by the animals on diets $F_{0}, F_{1.0}, F_{3.0}$ and $F_{5.0}$ in Exp. 1 was 15.0, 10.8, 13.2 and 12.2 and on diets $F_{0}, F_{1.0}$ and $F_{1.5}$ in Exp. 2 it was 20.5, 20.2 and 21.2, respectively.
\end{abstract}

\section{Introduction}

In earlier papers of SETÄLÄ and SYRJÄLÄ-QVIST(1982 a,b) it was reported that degradation of urea to ammonia in vitro could be decreased by treatment with formaldehyde. We also suggested that it would be possible to find the optimum treatment level for microbial protein synthesis. The aim of these experiments was to study the effects of formaldehyde-treated urea on rumen fermentation, ration digestibility and nitrogen utilization in vivo. 


\section{Materials and methods}

The rumen physiological and digestibility experiments were made in two trials arranged according to $4 \times 4$ (Experiment 1) and $3 \times 3$ (Experiment 2) Latin square designs with young Finn-sheep. In each treatment the transfer period lasted nine days and the collection period five days. In both trials the experimental diets were based on equal parts of $\mathrm{NaOH}$-treated wheat (Exp. 1) or barley (Exp. 2) straw and a concentrate mixture (Table 1). In addition, urea was mixed into the concentrate just before feeding. The urea tested in experiment 1 was untreated urea $\left(\mathrm{F}_{0}\right)$, and urea treated with $1.0\left(\mathrm{~F}_{1.0}\right), 3.0$ $\left(\mathrm{F}_{3.0}\right)$ and $5.0\left(\mathrm{~F}_{5.0}\right) \%$ formaldehyde on a weight basis. In experiment 2 the urea was untreated urea, and urea treated with 1.0 and $1.5\left(\mathrm{~F}_{1.5}\right) \%$ formaldehyde. The treatment of the urea was described by SETÄLÄ and SYRJÄLÄQVIST (1982 a).

The animals also received water and a mineral mixture $(24.0 \% \mathrm{Ca}, 6.0 \%$ $\mathrm{P}, 3.0 \% \mathrm{Mg}$ and $14.5 \% \mathrm{NaCl}$ ) ad libitum. The amounts consumed were calculated and recorded.

The feeds were sampled every day during the collection period and on the two first and last days of the transfer period. Thirty per cent of the total daily amount of the faeces was taken for analysis after thorough mixing. In Exp. 2 the urine was treated and sampled as described by SETÄLÄ et al. (1980). In Exp. 1 urine was sampled 1,3 and 4 hours after feeding and preserved without $\mathrm{H}_{2} \mathrm{SO}_{4}$. After this period the treatment and sampling were done as in Exp. 2.

In Exp. 1, in which rumen-fistulated animals were used, rumen samples were taken before and 1,2, 3 and 4 hours after feeding during the last two

Table 1. Chemical composition of the feeds.

\begin{tabular}{|c|c|c|c|c|c|c|}
\hline & DM, \% & Ash & $\begin{array}{l}\text { Crude } \\
\text { Protein }\end{array}$ & $\begin{array}{l}\text { Crude } \\
\text { fibre }\end{array}$ & $\begin{array}{l}\text { Ether } \\
\text { extracts }\end{array}$ & $\begin{array}{l}\mathrm{N} \text {-free } \\
\text { extracts }\end{array}$ \\
\hline & & \multicolumn{5}{|c|}{$\%$ in DM } \\
\hline \multicolumn{7}{|l|}{ Experiment } \\
\hline Wheat straw ${ }^{1}$ ) & 81.6 & 9.7 & 4.1 & 45.8 & 0.7 & 39.7 \\
\hline Concentrates $^{2}$ ) & 87.1 & 5.9 & 13.3 & 10.3 & 1.2 & 69.3 \\
\hline Urea, untreated $\left(\mathrm{F}_{0}\right)$ & 99.7 & - & $46,5^{4}$ & - & - & - \\
\hline Urea, $1 \%$ HCHO $\left(F_{1.0}\right)$ & 99.6 & - & $\left.46.5^{4}\right)$ & - & - & - \\
\hline Urea, $3 \%$ HCHO $\left(\mathrm{F}_{3.0}\right)$ & 98.9 & - & $\left.46.4^{4}\right)$ & - & - & - \\
\hline Urea, $5 \% \mathrm{HCHO}\left(\mathrm{F}_{5.0}\right.$ & 98.2 & - & $\left.46.5^{4}\right)$ & - & - & - \\
\hline \multicolumn{7}{|l|}{ Experiment 2} \\
\hline Barley straw ${ }^{1}$ ) & 75.4 & 12.6 & 3.3 & 44.2 & 0.9 & 39.0 \\
\hline Concentrates $^{3}$ ) & 86.4 & 6.4 & 12.8 & 2.6 & 67.4 & \\
\hline Urea, untreated $\left(\mathrm{F}_{0}\right)$ & 99.9 & - & $\left.46.4^{4}\right)$ & - & - & - \\
\hline Urea, $1 \%$ HCHO $\left(\mathrm{F}_{1.0}\right)$ & 99.4 & - & $\left.46.0^{4}\right)$ & - & - & - \\
\hline Urea, $1.5 \% \mathrm{HCHO}\left(\mathrm{F}_{1.5}\right)$ & 99.4 & - & $\left.46.2^{4}\right)$ & - & - & - \\
\hline
\end{tabular}

\footnotetext{
1) $\mathrm{NaOH}$-treated. $4 \% \mathrm{NaOH}$ in DM

$\left.{ }^{2}\right)$ Barley: Sugar beet pulp (1:1)

3) Barley: Oats: Sugar beet pulp (1:1:1)

4) $\mathrm{N} \%$
} 
days of the collection period. The samples were treated according to SYRJÄLÄ (1972).

Blood samples from the jugular vein (Vena jugularis) were taken in Exp. 1 on the first and fifth day of the collection period, five hours after feeding. This sampling time was chosen in accoordance with the results and suggestions of LEWIS (1957).

The chemical analyses of the feeds and faeces were made according to standard methods. Before analysis the samples were vacuum-dried $\left(+60^{\circ} \mathrm{C}\right)$ for two days and milled through a 1-mm screen. The dry matter content of the samples was determined by keeping them in $+105^{\circ} \mathrm{C}$ for 24 hours. The nitrogen content of the urea and urine was determined by the Kjeldahl method. In Exp. 1 the urea content of the urine sampled 1-4 hours after feeding was determined colorimetrically (ANON. 1973), and the urea in the faeces, excluding ammonia, was determined by the method of AOAC (ANON 1970). In Exp. 2 the non-dietary faecal nitrogen (NDFN) was determined according to MASON and FREDERIKSEN (1979), by using neutral detergent solutions. In Exp. 1 the pH, ammonia and VFA in the rumen samples were determined as explained by SETÄLÄ et al. (1980). The numbers of protozoa were calculated according to WESTERLING (1970) and those of bacteria in a Helberś counting chamber, with bottom area $1 \times 1 \mathrm{~mm}$, depth $0.02 \mathrm{~mm}$ and volume $0.02 \mathrm{~mm}^{3}$ (SYRJÄLÄ et al. 1976).

The blood samples were treated for the analyses as described by NÄSI (1979). Plasma urea-N and total proteins were determined according to CHANEY and MARBACH (1962) and REINHOLD (1953), respectively.

The statistical treatment of the results was made according to LUCAS (1975) and the differences between treatments were analyzed by the Tukey test (STEELE and TORRIE 1960).

\section{Results and discussion}

\section{Rumen fermentation}

The total concentration of VFA in the rumen tended to be lower, when $\mathrm{F}_{5.0}$ urea was used (Fig. 1). The differences between diets were not, however, significant. This kind of change was also noticed by KULASEK et al. (1975, 1976), who used similar treatment levels for urea, and by SYRJÄLÄ et al. (1978), when formaldehyde-treated skimmed-milk powder was studied.

Formaldehyde treatment tended to increase the proportion of acetid acid and decrease the proportion of isobutyric and butyric acids in the total VFA. Similar changes in acetic acid were found by FAICHNEY (1974) when using feed with a high content of rumen-degradable nitrogen treated with formaldehyde. However, this was not observed by SYRJÄLÄ et al. (1978) or KEMPTON and LENG (1979).

The proportions of isovaleric and valeric acids in the total VFA were relatively small. MÄKINEN (1972) showed that on urea-rich diets the amounts of branched-chain fatty acids in the rumen are low. In our experiment, 


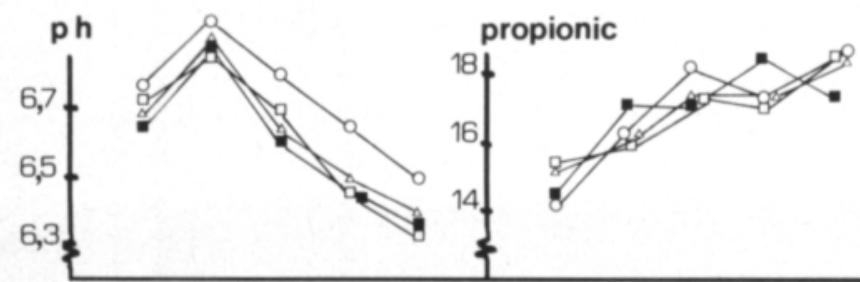

VFA total

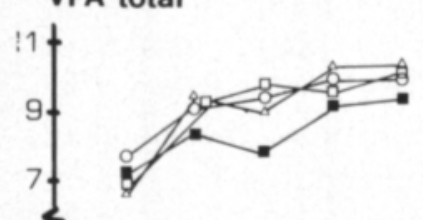

iso-, butyric

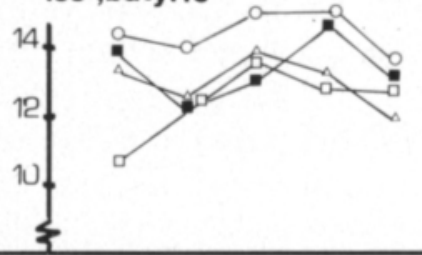

isovaleric, valeric

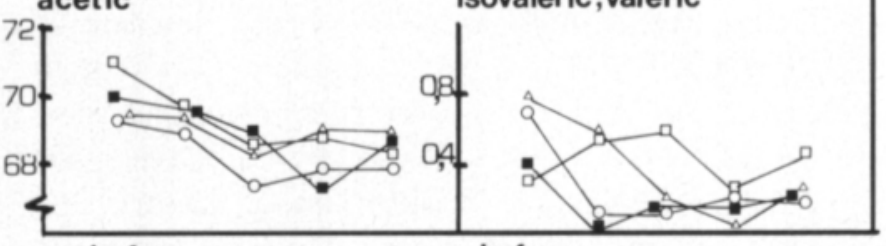

before

1

\section{$\begin{array}{lllll}2 & 3 & 4 & & \end{array}$}

TIME AFTER FEEDING, HOURS
Figure 1. Rumen $\mathrm{pH}$, total VFA and the molar proportions of VFA according to mole- $\%$ in the rumen fluid of sheep before and 1-4 hours after feeding. $\mathrm{OF}_{0}, \triangle \mathrm{F}_{1.0}$, $\square \mathrm{F}_{3.0}, \mathrm{~F}_{5.0}\left(\mathrm{~F}_{0}-\mathrm{F}_{5.0}\right.$, see Table 1.).

$\mathrm{NH}_{3} \mathrm{~N}$, MMOLES/L RUMEN FLUID

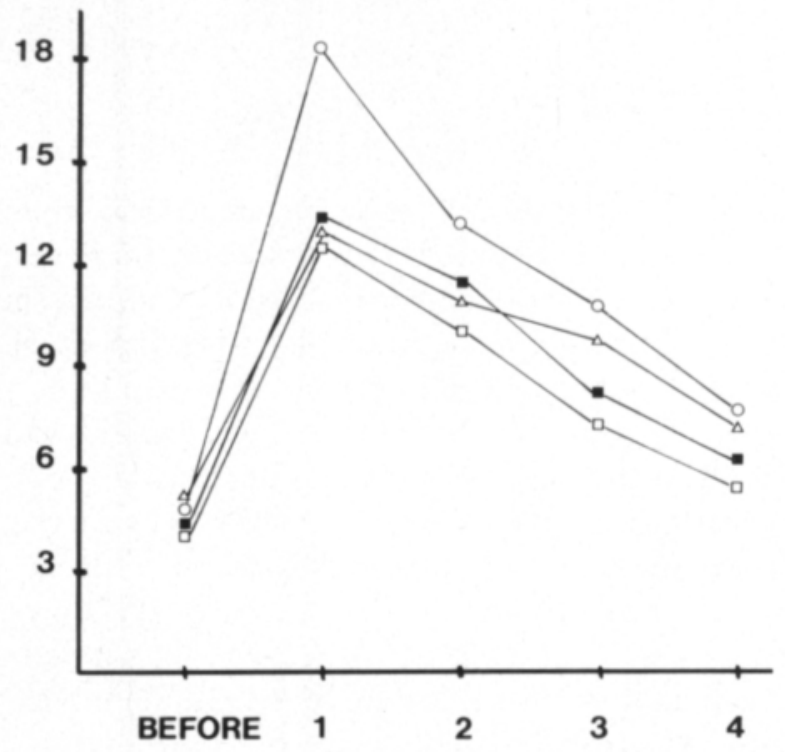

Figure 2. Rumen ammonia levels before and $1-4$ hours after feeding. $\mathrm{OF}_{0}$, $\triangle \mathrm{F}_{1.0} \square \mathrm{F}_{3.0} \mathrm{~F}_{5.0 \cdot}\left(\mathrm{F}_{0}-\mathrm{F}_{5.0}\right.$ see Table TIME AFTER FEEDING, HOURS 1). 
however, the proportions of isovaleric and valeric acids varied considerably, although not significantly, within the period studied.

Formaldehyde treatment caused a significant decrease $(P<0.05)$ in the peak of ammonia formation in the rumen (Fig. 2). Although differences were found between the urea treatments in vitro (SETÄLÄ and SYRJÄLÄ-QVIST a), they were not found in vivo. One explanation for this could be the change in the relationship between bacteria and protozoa in the rumen (Table 2). The amount of bacteria decreased $(\mathrm{P}<0.05)$ and the amount of protozoa increased $(\mathrm{P}<0.01)$ with a treatment level higher than $1 \%$ and $3 \%$ formaldehyde, respectively. If the decrease in the amounts of bacteria is caused by degradation of bacterial cells digested by protozoa, which is indicated by the changes in the concentrations of isovaleric and valeric acids in the rumen, then this degradation releases more ammonia into the rumen (COLEMAN 1975).

It appears also that the contribution of recycled urea nitrogen to the rumen ammonia levels was small (THORNTON 1970, KENNEDY and MILLIGAN 1978), and the main pathway was recycling in saliva (NOLAN and LENG 1972). Besides damage of bacteria cells by protozoa, decreased utilization of ammonia due to decreased fermentation and lack of fermentable energy for microbial protein synthesis (HAGEMEISTER et al. 1980) was another reason why the ammonia concentrations in the rumen did not differ between treatment levels in Exp. 1.

The changes in the amounts of different protozoa species were not very clear, although some significant differences were found. In treatments corres-

Table 2. Composition of rumen microbiota on different urea-containing diets (Experiment 1). $F_{\sigma}-F_{5.0}$, see Table 1.

\begin{tabular}{|c|c|c|c|c|}
\hline & $F_{0}$ & $F_{1.0}$ & $F_{3.0}$ & $\mathrm{~F}_{\mathrm{s}, 0}$ \\
\hline Bacteria. $\mathrm{n} \times 10^{9} / \mathrm{ml} \mathrm{RC}^{1}$ ) & $12.20^{a}$ & $12.60^{2}$ & $11.00^{b}$ & $9.90^{\circ}$ \\
\hline \multicolumn{5}{|l|}{ Protozoa, $\mathrm{n} \times 10^{3} / \mathrm{ml} \mathrm{RC}^{1}$ ) } \\
\hline Total & $51.30^{d}$ & $46.70^{d}$ & $53.80^{d}$ & $64.00^{e}$ \\
\hline Isotricha prostoma & $2.79^{d}$ & $0.59^{\circ}$ & $0.30^{\mathrm{e}}$ & $1.39^{f}$ \\
\hline Dasytricha ruminantium & $3.45^{\mathrm{d}}$ & $0.66^{\circ}$ & $0.69^{e}$ & $0.59^{\circ}$ \\
\hline Entodinium dubardi & $15.20^{d}$ & $17.66^{\mathrm{d}}$ & $24.73^{e}$ & $23.84^{\mathrm{e}}$ \\
\hline Entodinium nanellum & $19.38^{\mathrm{a}}$ & $15.94^{\mathrm{ab}}$ & $13.54^{b}$ & $20.21^{2}$ \\
\hline Entodinium caudatum & $1.10^{2 c}$ & $0.93^{a c}$ & $0.55^{b}$ & $1.15^{\mathrm{a}}$ \\
\hline Entodinium loboso-spinosum & $3.49^{d}$ & $1.33^{e}$ & $0.86^{f}$ & $1.13^{\mathrm{e}}$ \\
\hline Entodinium vorax & $2.43^{\mathrm{a}}$ & $1.26^{\mathrm{b}}$ & $1.08^{b}$ & $0.92^{b}$ \\
\hline Entodinium longinucleatum & $0.20^{d}$ & $0.20^{d}$ & $0.20^{d}$ & $0.99^{e}$ \\
\hline Entodinium dilobum & $1.12^{2}$ & $1.46^{\mathrm{b}}$ & $0.99^{2}$ & $1.56^{\mathrm{b}}$ \\
\hline Diplodinium dentatum & $4.45^{d}$ & $2.32^{e}$ & $2.99^{\circ}$ & $6.17^{f}$ \\
\hline Eudiplodinium maggii & $1.70^{d}$ & $0.99^{e}$ & $1.13^{\mathrm{e}}$ & $1.19^{e}$ \\
\hline Epidinium ecaudatum & $5.95^{2}$ & $3.38^{\mathrm{b}}$ & $6.78^{2}$ & $4.78^{a}$ \\
\hline g HCHO/100 g crude protein & - & 0.15 & 0.45 & 0.76 \\
\hline
\end{tabular}

1) $R C=$ rumen contents

$P<0.05$ a $-c$, means with different letters differ significantly.

$P<0.01 d-f$, means with different letters differ significantly. 
ponding to the present levels of 3 to $5 \%$ formaldehyde, the proportion of bacteria has generally increased and the proportion of protozoa decreased (HEMPEL-ZAWITKOWSKA and KULASEK 1974, KULASEK et al. 1976, SYRJÄLÄ et al. 1978), but compared with those results, the amounts of protozoa were rather low.

On the other hand, bacteria are removed from the rumen mainly in the liquid phase (BERGEN and YOKOYAMA 1977), while less than $30 \%$ of protozoa use this phase (WELLER and PILGRIM 1974). Since the water consumption increased with the formaldehyde treatment level $\left(r=+0.93^{x x}\right)$, this may have had an effect on the liquid flow from the reticulo-rumen (OYAERT and BOUCKAERT 1961, ROGERS et al. 1979) and hence on the proportions of bacteria and protozoa.

\section{Digestibility of the ration}

Formaldehyde treatment decreased the digestibility of the total ration most clearly at treatment levels higher than $1.5 \%$ (Table 3 ). When the apparent digestibility of crude protein is considered, significant $(P<0.05)$ differences are found only between the $F_{0}$ and $F_{5.0}$ diets. When the true digestibility of crude protein is calculated according to MASON (1979) using the values of non-dietary faecal nitrogen (Table 4), the results with $F_{0}, F_{1.0}$ and $F_{1.5}$ feeding in Exp. 2 were 89.7, 88.0 and $89.1 \%$ respectively. These values are similar to the results given by KAUFMANN (1977) and MASON and FREDERIKSEN (1979).

The main reason for the decreased digest $\mathrm{i}$ bility at the highest treatment

Table 3. The digestibility $\%$ of the total ration in different urea-containing diets. $\mathrm{F}_{0}-\mathrm{F}_{5.0}$, see Table 1 .

\begin{tabular}{|c|c|c|c|c|c|c|}
\hline & \multicolumn{5}{|c|}{ Urea treatments } & \multirow{2}{*}{$\begin{array}{l}\text { Tukeys's } \\
\text { LSD }\end{array}$} \\
\hline & $\mathrm{F}_{0}$ & $F_{10}$ & $F_{1,5}$ & $F_{3.0}$ & $F_{30}$ & \\
\hline \multicolumn{7}{|l|}{ Experiment 1} \\
\hline Dry matter & 76.0 & 76.1 & - & 74.0 & 72.8 & 4.9 \\
\hline Organic matter & 78.4 & 78.5 & - & 76.7 & 75.5 & 4.9 \\
\hline Crude protein & $79.6^{2}$ & $78.1^{a}$ & - & $75.4^{\mathrm{a}}$ & $73.3^{b}$ & 6.2 \\
\hline Crude fibre & 79.2 & 79.9 & - & 78.6 & 76.7 & 6.9 \\
\hline Ether extract & 64.7 & 65.0 & - & 60.4 & 60.4 & 10.4 \\
\hline $\mathrm{N}$-free extracts & 85.2 & 85.6 & - & 83.6 & 82.5 & 7.2 \\
\hline \multicolumn{7}{|l|}{ Experiment 2} \\
\hline Dry matter & 68.5 & 67.1 & 67.5 & - & - & 3.4 \\
\hline Organic matter & 69.1 & 67.7 & 68.1 & - & - & 3.3 \\
\hline Crude protein & 71.8 & 69.0 & 69.7 & - & - & 6.8 \\
\hline Crude fibre & 65.7 & 63.5 & 63.1 & - & - & 6.7 \\
\hline Ether extracts & 78.3 & 74.1 & 78.2 & - & - & 6.7 \\
\hline $\mathrm{N}$-free extracts & 75.6 & 72.3 & 72.4 & - & - & 5.2 \\
\hline $\mathrm{g} \mathrm{HCHO} / 100 \mathrm{~g}$ crude protein & - & 0.15 & 0.23 & 0.45 & 0.76 & \\
\hline
\end{tabular}

$\mathrm{P}<0.05, \mathrm{a}-\mathrm{b}$, see Table 2 . 
Table 4. Excretion of nitrogen in the faeces and urine, plasma urea- $\mathrm{N}$ and total protein, and nitrogen balance of the animals on different urea-containing diets. $\mathrm{F}_{0}-\mathrm{F}_{5.0}$, see Table 1.

\begin{tabular}{|c|c|c|c|c|c|c|}
\hline & \multicolumn{5}{|c|}{ Urea treatments } & \multirow{2}{*}{$\begin{array}{l}\text { Tukey' } \\
\text { LSD }\end{array}$} \\
\hline & $F_{0}$ & $F_{1.0}$ & $F_{1,5}$ & $F_{3.0}$ & $F_{5.0}$ & \\
\hline \multicolumn{7}{|l|}{ Experiment 1} \\
\hline $\mathrm{N}$ intake, $\mathrm{g} / \mathrm{d}$ & 21.3 & 21.2 & - & 21.2 & 21.3 & 0.2 \\
\hline $\mathrm{N}$ in faeces, $\mathrm{g} / \mathrm{d}$ & 4.3 & 4.6 & - & 5.2 & 5.7 & 1.3 \\
\hline - Urea-N g/d & 0.16 & 0.18 & - & 0.15 & 0.22 & 0.2 \\
\hline $\mathrm{N}$ in urine, $\mathrm{g} / \mathrm{d}$ & $13.8^{\mathrm{ab}}$ & $14.3^{\mathrm{a}}$ & - & $13.2^{\mathrm{ab}}$ & $13.0^{\mathrm{b}}$ & 1.1 \\
\hline - Urea-N, g/d & 11.9 & 11.5 & - & 12.2 & 11.2 & 1.1 \\
\hline $\mathrm{N}$ retained, \% of intake & 15.0 & 10.8 & - & 13.2 & 12.2 & 8.0 \\
\hline Plasma proteins, g/l & 66 & 70 & - & 66 & 68 & 9.9 \\
\hline Plasma urea- $\mathrm{N}, \mathrm{mmol} / \mathrm{l}$ & $3.3^{2}$ & $3.5^{\mathrm{a}}$ & - & $2.8^{\mathrm{b}}$ & $2.7^{b}$ & 0.46 \\
\hline \multicolumn{7}{|l|}{ Experiment 2} \\
\hline $\mathrm{N}$ intake, $\mathrm{g} / \mathrm{d}$ & 23.4 & 23.2 & 22.2 & - & - & 1.8 \\
\hline $\mathrm{N}$ in faeces, $\mathrm{g} / \mathrm{d}$ & 6.6 & 7.2 & 6.8 & - & - & 1.6 \\
\hline - non-dietary $\mathrm{N} \mathrm{g/d}$ & 5.7 & 6.0 & 5.9 & - & - & 0.3 \\
\hline $\mathrm{N}$ in urine, $\mathrm{g} / \mathrm{d}$ & 12.0 & 11.7 & 11.5 & - & - & 1.0 \\
\hline $\mathrm{N}$ retained, $\%$ of intake & 20.5 & 20.2 & 21.2 & - & - & 6.1 \\
\hline g HCHO $/ 100$ g crude protein & - & 0.15 & 0.23 & 0.45 & 0.76 & \\
\hline
\end{tabular}

$P<0.05, a-b$ see Table 2.

levels may be the change in the rumen microbiota. The ability of protozoa to digest crude fibre is poor compared with that of bacteria (HUNGATE 1966, HARMEYER 1973), although at least some species can digest and utilize hemicellulose and cellulose (HAYER et al. 1976, COLEMAN 1978).

\section{Utilization of nitrogen}

There were no significant differences in nitrogen retention of the animals on different diets (Table 4).

According to ANDERSON et al. (1959), increased excretion of nitrogen in faeces is caused by overprotected and hence undigested urea nitrogen. In Exp. 1 the method used for urea determination revealed no significant differences between treatments in the urea content of the faeces. It is possible that part of the treated urea not degraded in the rumen was degraded to ammonia in the caecum and was used for synthesis of microbial protein (TELLER et al. 1979). This could be an important factor for the apparent digestibility of crude protein. In Exp. 2 however, no significant differences were found in the excretion of non-dietary faecal nitrogen below the treatment level of $1.5 \%$ formaldehyde.

Since the digestibility of organic matter and the fermentation in the rumen were higher on the $\mathrm{F}_{1 . \mathrm{o}}$ diet than on the other diets containing treated urea in Exp. 1, less fermentable energy was available in the caecum on this diet. This decreases utilization of ammonia in the caecum and, together with 
possible degradation of $\mathrm{F}_{1.0}$ urea in the digestive tract before the caecum, affects the blood urea-N levels (CHALMERS et al. 1976).

Acknowledgements. The authors wish to express their gratitude to Kemira Ltd. for preparing the treated urea and to Mrs. Irma Immonen, Mr. Risto Kauppinen and Mr. Pentti Aspila for technical assistance during the experiment.

\section{References:}

ANDERSON, G. C., McLAREN, G. A., WelCH, J. A., CAMPBELL, C. D. \& SMITH, G. A. 1959. Comparative effects of urea, uramite, biuret, soybean protein and creatine on digestion and nitrogen metabolism in lambs. J. Anim. Sci. 18: 134-140.

ANON. 1970. Official methods of analysis of the Association of Official Analytical Chemistry. 11th ed. p. 125. Wisconsin.

ANON. 1973. The Analysis of Agricultural Material. Tech. Bull. 27. Ministry of Agriculture, Fisheries and Food. London.

BERGEN, W. G. \& YOKOYAMA, M. T. 1977. Production limits to rumen fermentation. J. Anim. Sci. 46: 573-584.

CHALMERS, M., GRANT, I. \& WHIRE, F. 1976. Nitrogen passage through the wall of the ruminant digestive tract. Protein metabolism and nutrition, EAAP-publ. 16: 159-179.

CHANEY, A. L. \& MARBACH, E. P. 1962. Modified reagents for determination of urea and ammonia. Clin. Chem. 8: 130-132.

COLEMAN, G. S. 1975. The interrelationship between rumen ciliate protozoa and bacteria. Digestion and metabolism in the ruminant, ed. McDonald, I. W. \& Warner, A. C. I. p. 149-164. Univ. New England Publ. Unit, Australia.

COLEMAN, G. S. 1978. The metabolism of cellulose, glucose and starch by the rumen ciliate protozoon Eudiplodium maggii. J. Gen. Microbiol. 107: 359-366.

FAICHNEY, G. J. 1974. The effect of formaldehyde treatment of a casein supplement on urea excretion and on digesta composition in sheep. Aust. J. Agric. Res. 25: 599-612.

HAGEMEISTER, H., LÜPPING, W. \& KAUFMANN, W. 1980. Microbial protein synthesis and digestion in the high-yielding dairy cow. Recent advances in animal nutrition -1980, ed. Haresign, W. p. 67-84. Butterworths.

HARMEYER, J. 1973. Protozoologie des Pansens. Biologie und Biochemie der mikrobiellen Verdauung, ed. Giesecke D. and Henderickx H. p. 58-107. BLV Verltagsgesellschaft. München, Bern, Wien.

HAYER, G. S., PUNJ, M.-L. \& BHATIA, I. S. 1976. Studies on hemicellulase of rumen protozoa from buffalo (Bubalus bubalis). Indian J. Anim. Sci. 46: 587-592.

HEMPEL-ZAWITKOWSKA, J. \& KULASEK, G. 1974. Influence of nitrogen components on the sheep's diet on the protozoa counts and protozoa genera in the rumen. Prace i Materialy Zootechniczne 6: 13-22.

HUNGATE, R. E. 1966. The rumen and its microbes. New York. 544 p.

KAUFMANN, W. 1977. Calculation of the protein requirements for dairy cows according to measurements of $\mathrm{N}$ metabolism. Protein Metabolism and Nutrition, p. 130-132. The Netherlands.

KEMPTON, T. J. \& LENG, R. A. 1979. Protein nutrition of growing lambs 1. Responses in growth and rumen function to supplementation of a low-protein-cellulosic diet with either urea, casein or formaldehyde treated casein. Br. J. Nutr. 40: 149-154.

KENNEDY, P. M. \& MILLIGAN, L. P. 1978. Transfer of urea from the blood to the rumen of sheep. Br. J. Nutr. 40: 149-154.

KULASEK, G., LEONTONOWICZ, H. \& KRASICKA, B. 1975. Urea-furfural polymer (UFP) as a protein replacer for sheep. Roczniki Nauk Rolniczych B. 96: 67-76.

— , LEONTONOWICZ, H., KRASICKA. B. \& HEMPEL-ZAWITKOWSKA, J. 1976. Influence of intraruminal drenching with urea and ureafurfural polymer (UFP) on the rumen and blood indices of starved or fed wethers. Roczniki Nauk Rolniczych B. 98: 57-65.

LEWIS, D. 1957. Blood urea concentration in relation to protein utilization in the ruminant. J. agric. Sci., Camb. 48: 438-446. 
LUCAS, H. L. 1975. Design and analysis for nutrition research. Vet. Agric. Univ. Copenhagen, Denmark. 155 p.

MASON, V. C. 1979. The quantitative importance of bacterial residues in the non-dietary faecal nitrogen of sheep 2. Estimates of bacterial nitrogen in faecal material from 47 digestibility trials. $Z$. Tierphys. Tierern. u. Futtermittelk. 41: 140-149.

MASON, V. C. \& FREDERIKSEN, J. H. 1979. Partition of nitrogen in sheep faeces with detergent solutions, and its application to the estimation of the true digestibility of dietary nitrogen and the excretion of non dietary faecal nitrogen. Z. Tierphys. Tierern. u. Futtermittelk. 41: 121-131.

MÄKINEN, S. 1972. Aspects of the nitrogen metabolism and nutritional status of urea-fed dairy cattle. Ann. Acad. Sci. Fenn. A. II. 165: 1-67 p.

NOLAN, J. V. \& LENG, R. A. 1972. Dynamic aspects of ammonia and urea metabolism in sheep. Br. J. Nutr. 27: 177-194.

NÄSI, M. 1979. Dried poultry manure as a feed ingredient for dairy cows. J. Scient. Agric. Soc. Finl. 51: 79-148.

OYAERT, W. \& BOUCKAERT, J. H. 1961. A study of the passage of fluid through the sheep's omasum. Res. Vet. Sci. 2: 41-52.

REINHOLD, J. G. 1953. Total protein, albumin and globulin. Standard Methods Clin. Chem. I: 88-97. New York.

ROGERS, J, A., MARKS, B. C., DAVIS, C. L. \& CLARK, J. H. 1979. Alteration of rumen fermentation in steers by increasing rumen fluid dilution rate with mineral salts. J. Dairy Sci. 62: 1599-1605.

SETÄLÄ, J., SEPPÄLÄ, J., PIRINEN, S., POUTIAINEN, E. \& PULLI, S. 1980. Maize for silage II. The effect of urea and acid as preservative treatment on rumen fermentations and on feeding values of silages. J. Scient. Agric. Soc. Finl. 52: 75-84.

SETÄLÄ, J. \& SYRJÄLÄ-QVIST. L. 1982a. The degradation and utilization of formaldehyde-treated urea by rumen microbes in vitro. J. Scient. Agric. Soc. Finl. 54: 15-24.

- \& SYRJÄLÄ-QVIST, L. 1982b. Effect of the crude protein level on the utilization of untreated and formaldehyde-treated urea in vitro. J. Scient. Agric. Soc. Finl. 54: 25-31.

STEEL, R. G. \& TORRIE, J. H. 1960. Principles and procedures of statistics. New York. 481 p.

SYRJÄLÄ, L. 1972. Effect of different sucrose, starch and cellulose supplements on the utilization of grass silages by ruminants. Ann. Agr. Fenn. 11: 199-276.

SYRJÄLÄ, L., SALONIEMI H. \& LAALAHTI, L. 1976. Composition and volume of the rumen microbiota of sheep fed on grass silage with different sucrose, starch and cellulose supplements. J. Scient. Agric. Soc. Finl. 48: 138-153.

- , SYVÄOJA, E. \& BOMAN, M. 1978. Utilization of untreated and formaldehyde treated skimmilk powder and skimmilk powder-barley pellets by ruminants. J. Scient. Agric. Soc. Finl. 50: 166-176.

TELLER, E., GODEAU, J-M. \& DE BAERE, R. 1979. The fate of nitrogen in the various segments of the digestive tract of cows. Z. Tierphys. Tierern. u. Futtermittelk. 42: 263-270.

THORNTON, R. F. 1970. Factors affecting the urinary excretion of urea nitrogen in cattle II. The plasma urea nitrogen concentration. Aust. J. Agric. Res. 21: 145-152.

WELLER, R. A. \& PILGRIM, A. F. 1974. Passage of protozoa and volatile fatty acids from the rumen of the sheep and from a continuous in vitro fermentation system. Br. J. Nutr. 32: 341-351.

WESTERLING, B. 1970. Rumen ciliate fauna of semi-domestic reindeer (Rangifer Tarandus L.) in Finland: Composition, volume and some seasonal variations. Acta Zoolog. Fenn. 127: 1-76.

Ms received March 23, 1982. 


\title{
Formaldehydillä käsitellyn urean vaikutus pötsikäymiseen, rehuannok- sen sulavuuteen ja typen hyväksikäyttöön.
}

\author{
Jouko Setälä ja Liisa Syrjälä-Qvist
}

Helsingin yliopisto, kotieläintieteen laitos, 00710 Helsinki 71

Kahdessa kokeessa selvitetiin formaldehydillä käsitellyn urean vaikutusta pötsikäymiseen (koe 1), rehuannoksen sulavuuteen ja typen hyväksikäyttöön (kokeet 1 ja 2) kuivalipeöityyn vehnän tai ohran olkeen perustuvalla ruokinnalla. Urea annettiin koe-eläiminä käytetyille lampaille ruokinnan yhteydessä väkirehuun sekoitettuna kaksi kertaa päivässä. Väkirehuna oli ohran ja melassileikkeen tai ohra-kauran ja melassileikkeen seosta. Olkea ja väkirehua annettiin suhteessa $1: 1$, molempia $0.5-0.6 \mathrm{kiloa} / \mathrm{eläin} / \mathrm{d}$, ja ureaa 20 grammaa/eläin/d. Urean käsittelytasot olivat kokeessa $10\left(\mathrm{~F}_{0}\right), 1.0\left(\mathrm{~F}_{1.0}\right), 3.0\left(\mathrm{~F}_{3.0}\right)$ ja $5.0\left(\mathrm{~F}_{5.0}\right)$ sekä kokeessa $20,1.0$ ja $1.5\left(\mathrm{~F}_{1.5}\right)$ painoprosenttia formaldehydiä.

Koko rehuannoksen sulavuus aleni selvästi, kun ruokinnassa oli $F_{3.0^{-}}$ja $F_{5.0^{-}}$ureaa. Sulavuuden aleneminen oli merkitsevä $(\mathrm{P}<0.05)$ vain raakavalkuaisen näennäisessä sulavuudessa $\mathrm{F}_{0}$ - ja $\mathrm{F}_{5.0}$-ruokinnan välillä. Pötsin bakteerien määrä väheni $(P<0.05)$ ja alkueläinten määrä vastaavasti lisääntyi $(P<0.01)$ $\mathrm{F}_{3.0^{-}}$ja $\mathrm{F}_{5.0}$-ruokinnoilla.

Pötsin haihtuvien rasvahappojen suhteissa tai kokonaismäärissä ei tapahtunut merkitseviä muutoksia. Rasvahappojen kokonaismäärä oli alhaisempi sïrryttäessä urean kolmea prosenttia suuremmille formaldehydi-käsittelytasoille.

Urean formaldehydi-käsittely vähensi virtsassa erittyvän typen määrää, mutta lisäsi typen erittymistä sonnassa. Eläinten typpitaseissa ei ollut merkitseviä eroja eri ruokintojen välillä. Pidättyneen typen osuudet syödyn typen kokonaismäärästä olivat $F_{0}-, F_{1.0}-, F_{3.0}-$ ja $F_{5.0}$-ruokinnalla (koe 1) sekä $F_{0}-, F_{1.0}$ - ja $F_{1.5}$ - ruokinnalla (koe 2) vastaavasti 15.0, 10.8, 13.2 ja 12.2 sekä 20.5, 20.2 ja 21.2 prosenttia. 